\title{
Teknik Teks Modelling: Meningkatan Hasil Belajar Menulis Puisi Pada Bidang Studi Bahasa Indonesia
}

\author{
Yayuk Widyawati ${ }^{(1)}$ \\ ${ }^{1}$ Sekolah Dasar Negeri 2 Petung Kecamatan Dongko \\ Email: ${ }^{1}$ yayukwid@gmail.com \\ DOI: https://doi.org/10.28926/riset_konseptual.v2i2.37
}

\begin{abstract}
ABSTRAK
Kemampuan menulis puisi adalah kecakapan yang dimiliki siswa untuk mengekspresikan pengalaman batin secara tertulis dalam bentuk larik dan bait. Faktor penghambat yang dialami siswa dalam menulis puisi adalah siswa kurang mengkomunikasikan pikiran dan perasaannya karena suasana kelas kurang kondusif, rendahnya kosa kata yang dimiliki siswa, guru menggunakan metode ceramah. Upaya perbaikan yang dilakukan dengan tindakan perbaikan pembelajaran dengan menggunakan teknik teks Modelling. Jenis penelitian ini berupa tindakan kelas yang terdiri dari 2 siklus. Masing-masing siklus terdiri dari empat tahap yaitu tahap perencanaan, pelaksanaan, observasi, dan refleksi. Analisis data yang digunakan meliputi tahap mereduksi data, menyajikan data, dan verifikasi data atau menarik kesimpulan. Subyek penelitian adalah siswa kelas $\mathrm{V}$ sebanyak 10 orang. Instrumen penelitian berupa tes, lembar observasi, dan dokumentasi. Hasil penelitian menunjukkan peningkatan rata-rata hasil belajar siswa pada setiap siklusnya, yaitu 58,62 pada studi awal, 65,52 pada siklus pertama, dan 76,21 pada siklus terakhir serta didukung dengan peningkatan ketuntasan belajar dimana pada studi awal hanya 7 orang siswa (24.14\%) menjadi 18 siswa (62.07\%) pada siklus pertama dan pada siklus terakhir menjadi 27 siswa (93.10\%). Dari penjelasan di atas disimpulkan bahwa penggunaan model pembelajaran dengan teks modelling terbukti meningkatkan hasil belajar siswa kelas $\mathrm{V}$ SDN 2 Petung Kecamatan Dongko Kabupaten Trenggalek pada materi menulis puisi.
\end{abstract}

Kata kunci: hasil belajar, bahasa Indonesia, modelling

\section{PENDAHULUAN}

Bahasa memiliki fungsi yang cukup penting sebagai sarana belajar. Dalam Keterampilan berbahasa terbagi menjadi empat yaitu keterampilan menyimak, berbicara, membaca, dan menulis. Kenyataan di lapangan observasi awal, menunjukan bahwa sebagian siswa menganggap pembelajaran menulis puisi merupakan pembelajaran yang sulit, membosankan, kurang menarik, dan monoton. Dengan kata lain sebagian besar dari mereka belum pernah mengalami pembelajaran menulis puisi yang menyenangkan. Kegiatan menulis tentunya berbeda dengan kegiatan secara lisan atau berbicara dan bahkan banyak siswa yang beranggapan bahwa menulis adalah suatu hal yang lebih sulit dibanding dengan berbicara atau kegiatan lisan lainnya. Melihat keadaan tersebut sepertinya penggunaan media yang menarik dan sesuai dengan materi yang diajarkan akan turut membantu dalam proses belajar mengajar.

Melalui penggunaan media diharapkan dapat mempertinggi kualitas hasil belajar siswa. Karena, media pengajaran merupakan suatu bagian integral dari proses pendidikan di sekolah. Salah satu bentuk media pembelajaran untuk meningkatkan keterampilan membaca adalah dengan menggunakan media visual. Penggunaan media visual dalam pembelajaran membaca, dianggap tepat karena dapat dihayati oleh peserta didik dengan cara dipandang..

\section{METODE}

Peneltian dilakukan dengan menggunakan metode yang memfokuskan kepada situasi kelas, dengan istilah Penelitian Tindakan Kelas (PTK) atau 
Classroom Action Research Wardhani (2009:14). Penelitian ini merupakan penelitian berlanjut (siklus) yang terdiri dari dua siklus dengan empat kegiatan utama, yaitu perencanaan, tindakan, observasi, dan refleksi, seperti model PTK (Penelitian Tindakan Kelas) yang dikembangkan oleh Kemmis dan McTaggart. Prosedur penelitian tindakan kelas ini terdiri dari tiga siklus. Dalam penelitian ini peneliti memakai model yang dikembangkan oleh Stephen Kemmis dan Robbin Mc Taggart. Menurut Stephen Kemmis dan Robbin Mc Taggart dalam satu putaran atau siklus terdiri atas empat komponen yaitu (1) perencanaan (planning), (2) tindakan (acting), (3) observasi (observing), dan (4) refleksi (reflecting). Setelah satu siklus selesai diimplementasikan, khususnya setelah refleksi, kemudian diikuti dengan adanya perencanaan ulang (replanning) atau revisi terhadap implementasi siklus sebelumnya (Basuki Wibawa, 2003:18). Penelitian Tindakan Kelas (PTK) merupakan suatu pencermatan terhadap kegiatan belajar berupa suatu tindakan, yang sengaja dimunculkan dan terjadi dalam suatu kelas secara bersama (Arikunto, 2011:3). Penelitian Tindakan Kelas ini dilaksanakan di Kelas V SDN 2 Petung pada semester ganjil tahun pelajaran 2016/2017 dengan jumlah siswa sebanyak 29 orang terdiri dari 13 siswa laki-laki dan 16 siswa perempuan.

\section{Rancangan Penelitian}

Penelitian yang dilaksanakan ini menggunakan Penelitian Tindakan Kelas (PTK ) Sesuai dengan jenis penelitian yang dipilih, yaitu penelitian tindakan, maka penelitian ini menggunakan model penelitian tindakan dari Kemmis dan Taggart (Wiriatmadja, 2006:6), yaitu berbentuk spiral dari sklus yang satu ke siklus yang berikutnya. Setiap siklus meliputi planning (rencana), action (tindakan), observation (pengamatan), dan reflection (refleksi). Langkah pada siklus berikutnya adalah perncanaan yang sudah direvisi, tindakan, pengamatan, dan refleksi. Sebelum masuk pada siklus 1 dilakukan tindakan pendahuluan yang berupa identifikasi permasalahan.

\section{Perencanaan}

Tahap ini adalah tahap pertama dalam penelitian. Tentunya segala sesuatu pasti didahului dengan adanya perencanaan. Ada beberapa aktifitas yang dapat dilakukan pada tahap perencanaan sebagai berikut mengidentifikasi masalah yang terjadi pada proses pembelajaran, merencanakan pembelajaran sesuai dengan hasil refleksi, mengembangkan skenario pembelajaran dalam bentuk RPP, menyusun LKS sesuai dengan materi, menyiapkan sumber dan media pembelajaran, menyusun soal evaluasi, dan menyusun format pengamatan.

\section{Pelaksanaan}

Hal yang dilakukan adalah apa yang tertuang pada tahap perencanaan, dan sesuai dengan model pembelajaran yang langkah pelaksanaan tindakan dengan model pembelajaran teknik teks modelling.

\section{Pengamatan}

Selama pembelajaran berlangsung, tidak hanya menanamkan konsep kepada siswa. Tetapi lebih jauh dari itu, melakukan pengamatan. Hal-hal yang diamati adalah tentang aktifitas siswa selama kegiatan pembelajaran khususnya pada saat kegiatan inti berlangsung. Pedoman yang dipergunakan adalah lembar pengamatan, memberi tanda check list $(\sqrt{ })$.

\section{Refleksi}

Refleksi merupakan bagian yang sangat penting untuk memahami dan memberikan makna terhadap proses dan hasil pembelajaran. Guru (observer) dan guru (peneliti) mendiskusikan hasil proses pembelajaran yang telah dilaksanakan. Dari data hasil observasi rekan sejawat dan data hasil observasi 
peneliti terhadap siswa, maka diperoleh gambaran tentang pembelajaran bahasa Indonesia yang dilakukan. Dengan data tersebut, guru (peneliti) dapat menentukan langkah berikutnya yaitu memperbaiki proses pembelajaran dan menyusun tindakan untuk siklus berikutnya. Tahapan ini merupakan kegiatan mengevaluasi dan meninjau kembali pelaksanaan pembelajaran dan hasil observasi yang dilakukan sebagai bahan pertimbangan untuk melakukan perbaikan sebagai tindak lanjut. Tahap merefleksi untuk mencari beberapa masukan dari proses pembelajaran yang baru saja dilakukan, menemukan hal-hal yang dianggap agak fatal dalam melaksanakan kegiatan pembelajaran, yang untuk selanjutnya dapat dicarikan jalan keluarnya.

\section{Teknik Pengumpulan Data}

Teknik pengumpulan data dalam pelaksanana penelitian ini menggunakan lembar tes ini bertujuan untuk melihat hasil kerja siswa secara berkelompok dalam mengaplikasikan konsep-konsep yang telah dikuasainya. Tes ini berisi tentang beberapa kegiatan siswa yang berupa tugas, latihan atau permasalahan. Tes.

\section{Teknik Analisa Data}

Pengolahan data dalam penelitian ini adalah dengan menggunakan analisis data secara kualitatif. Analisis data yang kualitatif digunakan untuk menganalisis data yang terjadi selama pembelajaran berlangsung sesuai dengan permasalahan dalam penelitian ini yaitu terhadap penerapan teknik Modelling Teks. Sedangkan analisis kuantitatif digunakan untuk melihat ada tidaknya peningkatan terhadap hasil belajar siswa, data yang diperoleh dari hasil tes evaluasi secara individual untuk melihat peningkatan pemahaman siswa dan hasil belajar siswa dalam teknik modelling teks. Adapun indikator yang digunakan untuk mengukur peningkatan keaktifan belajar adalah keterlibatan siswa secara aktif dalam proses pembelajaran dan pelaksanaan tugas selama mengikuti kegiatan pembelajaran.

Data mengenai hasil belajar diambil dari kemampuan kognitif peserta didik dalam memecahkan masalah dianalisis dengan menghitung rata-rata nilai ketuntasan belajar dan menghitung ketuntasan klasikal. Kriteria untuk mengukur tingkat keberhasilan upaya perbaikan pembelajaran adalah kriteria siswa tuntas belajar apabila telah mencapai tingkat penguasaan materi pembelajaran sebesar $80 \%$ ke atas atau mendapat nilai 80 , proses perbaikan pembelajaran dinyatakan berhasil apabila $85 \%$ dari jumlah siswa tuntas belajar, dan proses perbaikan pembelajaran (peningkatan keaktifan siswa) dinyatakan berhasil jika 85\% dari jumlah siswa terlibat aktif dalam proses pembelajaran.

\section{HASIL}

Tahap pelaksanaan disusun berdasarkan data awal siswa kelas V SDN 2 Petung Kecamatan Dongko Kabupaten Trenggalek, sebagian besar siswa kurang mampu mengapresiasi sastra (menulis puisi). Hal tersebut dapat dilihat dari hasil pengamatan yang ditemukan di lapangan, yang berupa nilai tes siswa. Selanjutnya hasil pengamatan yang ditemukan di lapangan tersebut, dapat dijadikan data awal penelitian tentang menulis puisi dan merupakan salah satu indikator pembelajaran bahasa yang dijadikan tolak ukur nilai keberhasilan pembelajaran Bahasa Indonesia. Hasil belajar menulis puisi dengan penggunaan Teknik modelling teks diarahkan untuk pembentukan pemahaman struktur puisi, pembentukan kemampuan memahami model puisi dan pembentukan model puisi, serta pembentukan kemampuan menulis elemen puisi yang kemudian dikembangkan menjadi puisi bebas. 


\section{PEMBAHASAN}

Pelaksanaan kegiatan pembelajaran menulis puisi dengan penggunaan Teknik modelling teks, dilakukan mulai dalam dua siklus. Pada setiap pertemuan pembelajaran peneliti menetapkan rencana persiapan pembelajaran. Setiap siklus melakukan pembelajaran menulis puisi dengan mengunakan Teknik modelling teks. Pada setiap siklus peneliti mengadakan observasi dengan menggunakan lembaran kerja siswa yang telah ditetapkan.

\section{KESIMPULAN}

Berdasarkan hasil analisis data dan temuan yang diperoleh pada siklus pertama dan kedua dapat ditarik kesimpulan sebagai penggunaan Teks Modelling hasil belajar siswa dalam pembelajaran Bahasa Indonesia pada materi menulis puisi dapat meningkatkan hasil belajar siswa. Hal tersebut dapat dibuktikan dengan peningkatan rata-rata hasil belajar siswa pada setiap siklusnya, yaitu 58,62 pada studi awal, 65,52 pada siklus pertama, dan 76,21 pada siklus terakhir serta didukung dengan peningkatan ketuntasan belajar dimana pada studi awal hanya 7 orang siswa $(24.14 \%)$ menjadi 18 siswa $(62.07 \%)$ pada siklus pertama dan pada siklus terakhir menjadi 27 siswa (93.10\%).

\section{SARAN}

Berdasarkan kesimpulan di atas, peneliti dapat mengajukan beberapa saran, guru hendaknya menguasai berbagai pendekatan pembelajaran yang tepat untuk membelajari siswa agar berhasil memenuhi tuntutan pembelajaran, baik proses maupun hasil sehingga keberhasilan pembelajaran dapat tercapai, salah satu dari pendekatan pembelajaran adalah pendekatan kompetensi dan memberikan bimbingan dan arahan yang tepat serta mudah diikuti oleh siswa, khususnya pada saat siswa menempuh langkah-langkah belajar berdasarkan pendekatan kompetensi. Hal ini penting mengingat pada saat proses belajar sedang berlangsung potensi (kemampuan) siswa akan berkembang apabila guru melakukan upaya-upaya yang tepat untuk mengembangkannya.

\section{DAFTAR RUJUKAN}

Arikunto, Suharsimi. 2007. Penelitian Tindakan Kelas. Jakarta: PT. Bumi Aksara BSNP. 2006. Permendiknas RI No. 22 tahun 2006 tentang Standar Isi untuk Satuan Penddikan Dasar dan Menengah. Jakarta.

Hartati, Tatat, dkk. 2009. Pembinaan Dan Pengembangan Pembelajaran Bahasa Dan Sastra Indonesia. Bahan Belajar Mandiri-Universitas Pendidikan Indonesia. Bandung.

Mufidah, Siti Fauziatul. 2010. Pemanfaatan Media Gambar Ilustrasi Untuk Meningkatkan Kemampuan Menulis Puisi Pada Siswa Kelas III MI. Miftahul Huda 1 Manaruwi Kecamatan Bangil Kabupaten Pasuruan. Skripsi, Program Studi Pendidikan Guru Sekolah Dasar, Jurusan Kependidikan Sekolah Dasar dan Pra Sekolah, Fakultas IImu Pendidikan, Universitas Negeri Malang.

Nana, Sudjana, dan Rivai, Ahmad. 2010. Media Pengajaran. Bandung : Sinar Baru Algesindo.

Nur'aini, Umri, Indriyani. 2008. Bahasa Indonesia III. Jakarta : Depdiknas.

Nurhayati. 2001. Penilaian dalam Pengajaran Bahasa dan Sastra. Yogyakarta: BPFE.

Pradopo, D. 2009. Pengkajian Puisi. Yogyakarta: Gadjah Mada Universitiy Press.

Santosa, Puji. 2008. Materi dan Pembelajaran Bahasa Indonesia SD. Jakarta : Pusat Penerbitan Universitas Terbuka.

Sari, Anita Novita. 2010. Upaya Guru Meningkatkan Kemampuan Menulis Puisi Melalui Media Gambar di Kelas III SDN Pasir Kampung Kabupaten Cianjur. Skripsi Fakultas IImu Pendidikan. Program S1 PGSD Bumi Siliwangi. UPI Bandung. 
Vol. 2 No. 2, April 2018;

Tarigan. Djago. 2007. Pendidikan Bahasa dan Sastra Indonesia di Kelas Rendah. Proyek Peningkatan Mutu Guru Kelas SD setara D-II. Jakarta : Departemen Pendidikan dan Kebudayaan.

Wardani, dkk. 2009. Pemantapan Kemampuan Profesional (Panduan). Pusat Penerbitan Universitas Terbuka.

Wiriatmadja, Rochiati. 2006. Metode Penelitian Tindakan Kelas, UPI Bandung dan Rosda 